\title{
Farklı Çörek Otu (Nigella sativa L.) Genotiplerinin Kışlık Ekim Koşullarında Verim ve Verim Öğelerinin Araştırılması
}

\section{Investigation of Yield and Yield Components of Different Black Cumin (Nigella sativa L.) Genotypes Sown in Winter Period}

\section{Mustafa CAN}

İl Tarım ve Orman Müdürlüğü, Uşak mustafican@gmail.com

iD 0000-0003-1533-7039
Gönderilme Tarihi: Kabul Tarihi
6 Mart 2021 25 Nisan 2021

\section{ÖZET}

Bu çalışma, kışlık ekim zamanının farklı çörek otu genotiplerinde (popülasyon/çeşit) verim ve verim öğeleri üzerine etkisini belirlemek için yürütülmüştür. Uşak ekolojik şartlarında 20172018 yılı yetiştirme sezonunda yürütülen çalışmanın tarla denemeleri tesadüf blokları deneme desenine göre üç tekerrürlü olarak kurulmuştur. Araştırmada bitki materyali olarak dört farklı lokasyondan (Uşak, Hatay, Diyarbakır ve Burdur) birer çörek otu popülasyonu ile Çameli çeşidi kullanılmıştır. Çalışmada genotiplerin bitki boyu, bitki başına dal sayısı, bitki başına kapsül sayısı, kapsül başına tohum ağırlığı, bin tohum ağırlığ ve tohum verimi incelenmiştir. Varyans analizi sonuçlarına göre, incelenen tüm parametreler bakımından genotiplerin etkisi istatistiksel olarak önemli bulunmuştur. Çalışmada yer alan genotiplerin bitki boyu 30.23-35.77 cm, bitki başına dal sayısı 4.07-5.25 adet, bitki başına kapsül sayısı 2.87-4.70 adet, kapsül başına tohum ağırlığı 0.23-0.37 g, bin tohum ağırlığı 2.45-3.35 $\mathrm{g}$ ve tohum verimi $66.55-119.26 \mathrm{~kg} \mathrm{da}^{-1}$ arasında belirlenmiştir. Sonuç olarak, Hatay lokasyonundan temin edilen popülasyon Uşak ekolojik şartlarında en yüksek tohum verimi $(119.26 \mathrm{~kg}$ $\left.\mathrm{da}^{-1}\right)$ ile kışlık ekim zamanında öne çıkan popülasyon olmuştur.

Anahtar kelimeler: Çörek otu, tohum verimi, popülasyon, çeşit, kışlık ekim, 


\section{ABSTRACT}

This study was conducted to determine the effect of winter sowing on yield and yield components of different black cumin genotypes (population/variety). The field experimentals of the study, conducted under Uşak ecological conditions during the 2017-2018 growing season, were established in randomized complete block design with 3 replications. In this research, Çameli variety and populations of black cumin obtained from four different locations (Uşak, Hatay, Diyarbakır and Burdur) were used as plant materials. In the study, plant height, number of branches per plant, number of capsules per plant, seed weight per capsule, 1000 seed weight and seed yield of the genotypes were examined. According to the results of variance analysis, the effect of genotypes was found to be statistically significant in terms of all parameters examined. The plant height, number of branches per plant, number of capsules per plant, seed weight per capsule, 1000 seeds weight and seed yield of the black cumin genotypes were determined as $30.23-35.77 \mathrm{~cm}, 4.07-5.25,2.87$ $4.70,0.23-0.37 \mathrm{~g}, 2.45-3.35 \mathrm{~g}$ and $66.55-119.26 \mathrm{~kg} \mathrm{da}$ ${ }^{1}$, respectively. As a result, the population obtained from Hatay location was the prominent population in the winter sowing of Uşak ecological conditions with the highest seed yield (119.26 $\left.\mathrm{kg} \mathrm{da}^{-1}\right)$.

Keywords: Black cumin, seed yield, population, variety, winter sowing

\section{GİRIŞ}

Ranunculaceae familyasına ait en önemli türlerden biri olan çörek otu (Nigella sativa L.) tek yıllık otsu bir tıbbi bitkidir (Thilakarathna vd., 2018). Doğu Akdeniz, Güney Avrupa ve Orta Asya’nın doğal florasında yer alan (Wajs vd., 2008) Nigella cinsinin Türkiye florasında 12 türü (Nigella sativa L., Nigella damascena L., Nigella oxypetala L., Nigella arvensis L., Nigella orientalis L., Nigella latisecta $\mathrm{PH}$ Davis, Nigella elata Boiss., Nigella segetalis Bieb., Nigella nigellastrum (L.) Willk., Nigella unguicularis (Lam.) Spenner ve Nigella lancifolia Hub. -Mor.) bulunmaktadır. $\mathrm{Bu}$ türlerden Nigella sativa ve Nigella damascena türleri Türkiye'nin farklı bölgelerinde yetiştirilmekle birlikte yaygın olarak yetiştirilen tür Nigella sativa'dır ((Toncer ve Kız1l, 2004; Baydar, 2013).

Eski çağlardan beri farklı amaçlarla kullanılan kültür bitkilerinden biri olan çörek otu bitkisinin tohumu hem gıda olarak hem de alternatif tıpta kullanılmıştır (Gün, 2012). Sabit ve uçucu yağın yanı sıra alkaloidler (nigellisin ve nigelledin), protein ve saponin (a-hederin) ihtiva eden çörek otu tohumları (Özel vd., 2009), özellikle Ortadoğu ve Hindistan olmak üzere dünyanın birçok yerinde uzun yıllardır baharat olarak kullanılmaktadır (Kara vd., 2015; Thilakarathna vd., 2018). Asırlardır halk hekimliğinde; soğuk algınlığı, astım, sarılık, baş ağrısı, idrar söktürücü, romatizma, iltihap hastalıkları gibi birçok hastalığa karşı çörek otu tohumu ile tohumundan elde edilen preparatların çok fazla kullanıldığı bilinmektedir (Randhawa, 2008).

Çörek otunda bulunan tıbbi bileşenlerin (timokinon ve nigellon) anti-tümör, anti-enflamatuar ve anti-diyabetik özellik gösterdiği, kanser, kronik böbrek rahatsızlı̆ğ ve astım tedavisinde de fayda sağladığı rapor edilmiştir (Khan vd., 2011; Woo vd., 2012). Çörek otu tarımında önde olan ülkelerin Hindistan, Bangladeş, Sri Lanka, Pakistan, Afganistan, Mısır, Irak, Etiyopya, Suriye ve İran'ın yanı sıra Türkiye'nin de olduğu bildirilmiştir (Sultana vd., 2018). Nitekim Türkiye'de çörek otu tarımı son yıllarda hızla artmış, 2012 yılında 2.299 dekar alanda 161 ton çörek otu üretilirken, bu değerler 2019 yılı için 37.085 dekar alanda 3603 ton olarak kaydedilmiştir. Bununla birlikte 2019 yılında gerçekleşen çörek otu ihracatı ve ithalatı sırasıyla 592.4 ton (1.23 milyon \$) ve 2647.5 ton (2.53 milyon \$) olmuştur (Anonim, 2019a).

Türkiye'de Burdur, Uşak ve Konya illerinin çörek otu üretiminde önde gelen iller olduğu, 2019 yılı verileri incelendiğinde ise Ușak ilinin (8.735 da ekim alanında 777.4 ton üretim) Burdur ilinin ardından çörek otu üretiminde ikinci sırada bulunduğu görülmektedir (Anonim, 2019b; Can, 2020). Türkiye'de çörekotu üretiminin artmasına rağmen çörekotu üretiminin genel olarak yerel popülasyonlarla yapılması, bölgelere göre uygun ekim zamanının ayarlanamaması, yabancı otlarla etkili mücadele yapılamaması, kurak geçen yıllarda bitkinin 
ihtiyaç duyduğu su ihtiyacının karşılanamaması, hasat zamanının gecikerek tane kaybının meydana gelmesi gibi nedenlerle verim istenilen düzeyde değildir (Saraç, 2019; Can, 2020).

Ülkemizde çörek otu çoğunlukla kuru tarım alanlarında yazlık ekilen bir bitki olup, kışı çok sert geçmeyen bazı bölgelerde ise kışlik ekilebilmektedir. $\mathrm{Bu}$ bölgelerde münavebe içerisine alınması gereken çörek otu bitkisinin verimini sınırlandıran en önemli faktör bitkinin vejetasyon döneminde düşen yağışların yetersizliğidir. Özellikle Orta Anadolu ve Geçit kuşağı illerimizde çörek otu verimini arttırmak için uygun çeşitlerin geliştirilmesi ile birlikte bölgeler için en uygun ekim zamanlarının belirlenmesi de büyük öneme sahiptir. Yapılan bir çok araştırmada kışlık ekim koşullarında yetiştirilen bitkilerden yazlık ekim koşullarında yetiştirilen bitkilere kıyasla daha fazla verim alındığı belirlenmiştir (Paşa, 2008; Öz, 2014; Eren, 2020). Bir bölgede ekimin mümkün olduğunca erken yapılması durumunda (sonbahar veya erken ilkbaharda) bitkiler yağışlardan daha fazla yararlanmakta bu sebeple birim alandan daha yüksek verim elde edilmesi mümkün olmaktadır. Diğer taraftan bölgeye adapte olmuş uygun genotip (tescilli çeşit/popülasyon) seçimi, tarımsal üretimde daha yüksek verim ve kalite elde etmenin en önemli faktörlerinden biridir. Genellikle yerel popülasyonların bölgesel koşullara daha iyi uyum sağladığı bilinmektedir. Bununla birlikte her geçen gün yaygınlaşan ülkemiz tıbbi ve aromatik bitkiler tarımında tescilli çeşit sayısının çok az olması nedeniyle popülasyonlar tohumluk olarak daha yaygın kullanılmaktadır. Nitekim bir araştırmada çörek otu tarımında çiftçilerin tescilli bir çeşit (çameli) olmasına rağmen bu çeşidi sadece \% 1.37 oranında üretimde kullandığı, bir başka ifade ile \% 98.63 oranında çörek otu popülasyonlarının tohumluğunu kullandığı belirlenmiştir (Can, 2020). Bu nedenle çeşitli ekolojik koşullar altında bu popülasyonların verim ve kalite potansiyelinin belirlenmesi gerekmektedir. Çörek otu genotiplerinin verim, verim öğeleri ve kalite karakterleri üzerindeki etkisi birçok araştırmacılar tarafından incelenmiştir (Tektaş, 2015; Kara vd., 2015; Kılıç ve Arabacı, 2016; Koşar ve Özel, 2018; Saraç, 2019; Can vd., 2021). Ancak bu çalışmalar farklı ekolojik şartlarda, genellikle yazlık ekim zamanında veya kışlık ekim için ise sadece kışı çok sert geçmeyen bazı illerde (Aydın, Şanlıurfa vs.) yürütülmüştür.

$\mathrm{Bu}$ çalışmanın maksadı, Uşak ekolojik koşullarında kışlık ekilen farklı çörek otu genotiplerinin verim ve verim komponentleri açısından performanslarının karşılaştırılmasıdır.

\section{MATERYAL VE YÖNTEM}

Deneme 2017-2018 vejetasyon döneminde Uşak ili Merkez İlçesi Hocalar Köyü çiftçi tarlasında gerçekleştirilmiştir. Çalışmada bitki materyali olarak "Çameli" isimli tescilli çörek otu çeşidi ile Uşak, Hatay, Diyarbakır ve Burdur illerinde çörek otu yetiştiriciliği yapan çiftçilerden temin edilen 4 farklı çörek otu popülasyonu kullanılmıştır. Çalışma alanı topraklarının tekstürünün killi-tınlı, pH’ının hafif alkalin, orta kireçli, tuzluluk sorunu bulunmayan, organik maddesinin çok düşük, faydalanılabilir fosfor oranının çok az ve faydalanılabilir potasyum oranının ise yüksek olduğu tespit edilmiştir (Çizelge 1).

Araştırmanın yürütüldüğü Uşak ili geçit kuşağında

Çizelge 1. Çalışma alanı toprağının bazı fiziksel ve kimyasal özellikleri

\begin{tabular}{|c|c|c|c|c|c|c|}
\hline Tekstür & $\begin{array}{c}\text { Toplam } \\
\text { Kireç } \\
(\%)\end{array}$ & $\begin{array}{c}\mathrm{EC} \\
\left(\mathrm{ds} \mathrm{m}^{-1}\right)\end{array}$ & $\begin{array}{c}\text { Faydalanılabilir } \\
\mathrm{P}_{2} \mathrm{O}_{5}\left(\mathrm{~kg} \mathrm{da}^{-1}\right)\end{array}$ & $\begin{array}{c}\text { Faydalanılabilir } \\
\mathrm{K}_{2} \mathrm{O}\left(\mathrm{kg} \mathrm{da}^{-1}\right)\end{array}$ & $\begin{array}{c}\text { Organik } \\
\mathrm{MH} \\
(\%)\end{array}$ \\
\hline Killi-tınlı (2018) & 9.9 & 0.615 & 0.94 & 130.5 & 7.83 & 0.08 \\
\hline
\end{tabular}

Toprak analizi Uşak İl Tarım ve Orman Müdürlüğü Toprak Laboratuvarında yapılmıştır. 
Çizelge 2. Deneme alanına ait bazı iklim verileri

\begin{tabular}{|c|c|c|c|c|c|c|}
\hline \multirow[t]{2}{*}{ Aylar } & \multicolumn{2}{|c|}{$\begin{array}{l}\text { Toplam Yağı̧̧ } \\
(\mathrm{mm})\end{array}$} & \multicolumn{2}{|c|}{$\begin{array}{c}\text { Ortalama } \\
\text { Sicaklık }\left({ }^{\circ} \mathrm{C}\right)\end{array}$} & \multirow{2}{*}{$\begin{array}{c}\text { Minumum } \\
\text { Sicaklık }\left({ }^{\circ} \mathrm{C}\right) \\
2017-2018\end{array}$} & \multirow{2}{*}{$\begin{array}{c}\text { Maksimum } \\
\text { Sicaklik }\left({ }^{\circ} \mathrm{C}\right) \\
2017-2018\end{array}$} \\
\hline & $2017-2018$ & $\mathrm{UY}^{*}$ & $2017-2018$ & $\mathrm{UY}^{*}$ & & \\
\hline Kasım & 43.2 & 56.3 & 7.6 & 7.8 & -4.2 & 20.2 \\
\hline Aralık & 52.8 & 74.3 & 5.6 & 4.0 & -4.4 & 18.5 \\
\hline Ocak & 71.8 & 58.4 & 3.6 & 2.5 & -5.7 & 14.8 \\
\hline Şubat & 63.8 & 58.5 & 6.7 & 3.5 & -2.2 & 17.6 \\
\hline Mart & 76.8 & 51.1 & 9.3 & 6.4 & -0.9 & 20.0 \\
\hline Nisan & 6.4 & 57.7 & 15.4 & 11.2 & 1.9 & 28.5 \\
\hline May1s & 102.4 & 43.1 & 17.2 & 16.1 & 4.5 & 29.4 \\
\hline Haziran & 54.6 & 24.1 & 20.2 & 20.7 & 9.3 & 30.8 \\
\hline Temmuz & 58.2 & 15.5 & 23.7 & 24.4 & 13.7 & 33.3 \\
\hline Ağustos & 37.8 & 9.5 & 24.3 & 24.3 & 12.6 & 34.5 \\
\hline Toplam & 567.8 & 448.5 & - & - & - & - \\
\hline Ortalama & - & - & 13.36 & 12.09 & - & - \\
\hline
\end{tabular}

Kaynak : Uşak Meteoroloji Müdürlüğü *UY: Uzun Yıllar (1986-2016)

bulunmakta olup, çalışmanın yürütüldüğü dönemin uzun yıllar (1986-2016) ortalaması olarak 448.5 mm'lik yağışa sahip bir bölgedir. Bu yağışın büyük kısmı sonbahar, kış ve erken ilkbaharda düşmekte olup, yaz ayları kurak geçmektedir. Tarla çalışmasının yürütüldüğü Kasım 2017-Ağustos 2018 arası gerçekleşen yağış miktarları uzun yıllarla birlikte değerlendirildiğinde çalışmanın yürütüldüğü döneme ait yağışların daha yüksek olduğu görülmektedir. Ortalama aylık sıcaklıklar incelendiğinde ise uzun dönemde gözlemlenen ortalama sıcaklık değeri, çalışmanın yürütüldüğü döneme ait ortalama sıcaklık değerinden daha düşük gerçekleşmiştir. Ayrıca çalışma döneminde bölgede en düşük sıcaklık 2018 ocak ayında $-5.7^{\circ} \mathrm{C}$ olarak gözlemlenmiştir (Çizelge 2).

Tarla denemeleri, tesadüf blokları deneme deseninde 3 tekerrürlü olarak kurulmuştur. Tohumlar, dekara $1.5 \mathrm{~kg}$ hesabıyla, $2-3 \mathrm{~cm}$ derinliğe ve $25 \mathrm{~cm}$ sıra aralığında elle ekilmiştir. Tohum ekimleri 30 Kasım 2017 tarihinde gerçekleştirilmiştir. Her deneme parselinin uzunluğu $5 \mathrm{~m}$ olup parsellerde 4 sıra yer almıştır. Yabancı ot kontrolü gerektiğinde elle yapılmış, sulama uygulanmamıştır.

Deneme parselleri, saf olarak dekara $6 \mathrm{~kg} \mathrm{~N}$ ve $4 \mathrm{~kg}$ $\mathrm{P}_{2} \mathrm{O}_{5}$ olacak şekilde gübrelenmiştir. Çalışmada gübre kaynağ1 olarak Triple süper fosfat ile Amonyum sülfat kullanılmıştır. Fosforlu gübre bir defada ekim işlemi ile birlikte verilirken, azotlu gübrenin $1 / 2$ 'si ekim sırasında $1 / 2$ 'si üst gübre olarak bitkiler ilkbaharda $15 \mathrm{~cm}$ bitki boyuna ulaştığında verilmiştir. Hasatta, parsel kenarlarından birer sıra ve sıraların baș ve sonlarından $0.5 \mathrm{~m}$ kenar tesiri olarak bırakılmıştır. Hasat tarihleri bitki kapsüllerinin kahverengi renk almaya başladığı dönem dikkate alınarak belirlenmiş olup, bu tarihler çalışmada yer alan Çameli çeşidi, Uşak, Hatay, Diyarbakır ve Burdur popülasyonları için sırasıyla 13.08.2018, 13.08.2018, 06.08.2018，27.07.2018 ve 13.08.2018 tarihleri olmuştur. Araştırmada, genotiplerin bitki boyu, bitki başına dal sayısı, bitki başına kapsül sayısı, kapsül başına tohum ağırlığı, bin tohum ağırlığı ve tohum verimi özellikleri incelenmiştir. Her parselden rastgele seçilen 10 adet bitkinin ölçülüp tartılması ile tek bitki değerleri tespit edilmiş, parsel verimleri kullanılarak dekara tohum verimleri elde edilmiştir. Hasat öncesi ve sonrası yapılan ölçüm ve hesaplamalar Akgören (2011)'in belirttiği yöntemlere göre yapılmıştır.

Çalışmadan elde edilen veriler SPSS istatistik paket programı kullanılarak varyans analizine tabi tutulmuş, önemli olduğu belirlenen ortalama değerler arasındaki farklar Tukey testi $(\mathrm{P}<0.05)$ ile gruplandırılmıştır. 


\section{BULGULAR VE TARTIŞMA}

Uşak ekolojik koşullarında farklı çörek otu genotipleri ile yürütülen bu çalışmada çörek otu bitkisinin verim ve verim öğeleri incelenmiş, çalışma sonucunda incelenen tüm özellikler bakımından genotiplerin istatistiksel olarak önemli etki $(\mathrm{p}<0.01)$ gösterdiği belirlenmiştir (Çizelge 3).

Çalışmada yer alan genotiplerin bitki boyu değerleri 29.80$35.77 \mathrm{~cm}$ arasında bir değişim göstermiştir. En düşük
Bununla birlikte Taqi (2013)'nin 42.98-43.05 cm, Tektaş (2015)'ın 63.87-70.37 cm , Kılıç ve Arabacı (2016)'nın $39.33-78.90 \mathrm{~cm}$ ve Saraç (2019)' 1 n 60.50-74.43 cm olarak bildirdiği bitki boyu değerlerinden daha düşük olmuştur. Çalışmalarda elde edilen bitki boyu değerleri arasındaki farklılık, kullanılan bitki materyallerinin genetik yapısındaki değişim ve çalışma bölgelerinin farklı ekolojik koşulları ile açılanabilir.

Verim unsurlarının en önemlilerinden biri olan bitkide

Çizelge 3. Farklı çörek otu genotiplerinin verim ve verim öğeleri üzerine etkisi

\begin{tabular}{|c|c|c|c|c|c|c|}
\hline Genotipler & $\begin{array}{l}\text { Bitki boyu } \\
\quad(\mathrm{cm})\end{array}$ & $\begin{array}{c}\text { Bitki başına } \\
\text { dal sayısı } \\
\text { (adet) }\end{array}$ & $\begin{array}{c}\text { Bitki } \\
\text { başına kapsül } \\
\text { sayısı (adet) }\end{array}$ & $\begin{array}{c}\text { Kapsül } \\
\text { başına tohum } \\
\text { ağırlığı gr) }\end{array}$ & $\begin{array}{l}\text { Bin tohum } \\
\text { ağırlığı (gr) }\end{array}$ & $\begin{array}{c}\text { Tohum } \\
\text { verimi } \\
\left(\mathrm{kg} \mathrm{da}^{-1}\right)\end{array}$ \\
\hline Çameli & $30.23 \mathrm{~b}$ & $5.25 \mathrm{a}$ & $4.50 \mathrm{a}$ & $0.26 \mathrm{~b}$ & $3.00 \mathrm{a}$ & $66.55 \mathrm{~b}$ \\
\hline Uşak & $33.10 \mathrm{ab}$ & $4.07 \mathrm{~b}$ & $3.73 \mathrm{ab}$ & $0.24 \mathrm{~b}$ & $3.30 \mathrm{a}$ & $74.42 \mathrm{~b}$ \\
\hline Hatay & $35.77 \mathrm{a}$ & $5.12 \mathrm{a}$ & $4.70 \mathrm{a}$ & $0.37 \mathrm{a}$ & $3.20 \mathrm{a}$ & $119.26 \mathrm{a}$ \\
\hline Diyarbakır & $29.80 \mathrm{~b}$ & $4.30 \mathrm{ab}$ & $2.87 \mathrm{~b}$ & $0.30 \mathrm{ab}$ & $3.35 \mathrm{a}$ & $68.94 \mathrm{~b}$ \\
\hline Burdur & $33.47 \mathrm{ab}$ & $4.83 \mathrm{ab}$ & $4.43 \mathrm{a}$ & $0.23 \mathrm{~b}$ & $2.45 \mathrm{~b}$ & $81.09 \mathrm{~b}$ \\
\hline Ortalama & 32.47 & 4.71 & 4.05 & 0.28 & 3.06 & 82.05 \\
\hline Genotipler & $* *$ & $* *$ & $* *$ & $* *$ & $* *$ & $* *$ \\
\hline VK (\%) & 8.04 & 11.98 & 19.34 & 21.94 & 11.97 & 25.47 \\
\hline
\end{tabular}

**: P<0.01, VK: Varyasyon katsayısı

Aynı sütunlardaki aynı harfler arasında istatistiksel olarak fark yoktur.

bitki boyu değeri Diyarbakır yerel popülasyonundan elde edilirken, en yüksek değer ise Hatay yerel popülasyonundan elde edilmiştir (Şekil 1). Fakat Uşak, Hatay ve Burdur yerel popülasyonlarının bitkiboyları arasında istatistiki olarak fark bulunmamıştır. (Çizelge 3). Çalışmada incelenen çörekotu çeşit ve popülasyonlarına ait bitki boyu değerleri; Akgören (2011)'nin 16.6-25.2 cm olarak ve Kara vd. (2015)'nin Eskişehir lokasyonunda $18.5-26.0 \mathrm{~cm}$ olarak bildirdiği değerlerden yüksek, Tavas vd. (2014)'nın 32.33-35.47 cm olarak ve Kara vd. (2015)'nin Isparta lokasyonunda 29.0$36.8 \mathrm{~cm}$ olarak bildirdiği değerlere benzer bulunmuştur.

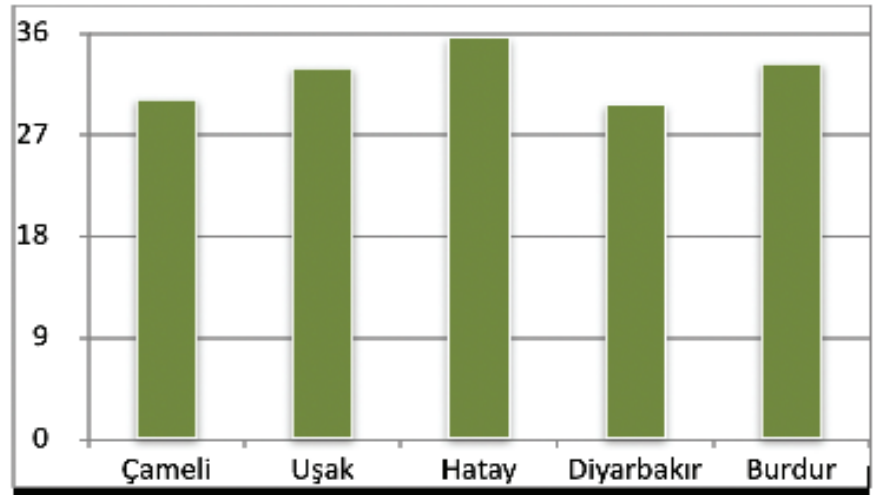

Şekil 1. Çörek otu genotiplerinin bitki boyu $(\mathrm{cm})$ 
dal sayısı bakımından genotipler 4.07-5.25 adet bitki ${ }^{-1}$ arasında değer almış, bitki başına dal sayısı bakımından genotiplerin etkisi istatistiksel açıdan önemli $(\mathrm{p}<0.01)$ olmuştur (Çizelge 3). En düşük bitki başına dal sayısı değeri Uşak yerel popülasyonundan elde edilirken, en yüksek değer 5.25 adet ile Çameli çeşidinden elde edilmiş, bunu 5.12 adet ile Hatay, 4.83 adet ile Burdur ve 4.30 adet ile Diyarbakır popülasyonları izlemiştir. Uşak popülasyonu hariç diğer genotipler bitkide dal sayısı bakımından istatistiksel olarak aynı grupta yer almıştır (Çizelge 3). Bu durum Uşak yerel popülasyonunun dallanma bakımından genotipik olarak diğer genotiplerden daha zayıf olduğunu göstermektedir. Bazı araştırmacılar (Taqi, 2013; Tavas vd., 2014) bitkide dal sayısı değerini bulgumuzdan düşük olarak 2.5-3.1 adet bitki ${ }^{-1}$ arasında bulduklarını rapor ederken, bazı araştırmacılar (Tonçer ve Kızıl, 2004; Tektaş, 2015) ise bulgularımızdan yüksek olarak 6.63-8.17 adet bitki ${ }^{-1}$ arasında bulduklarını bildirmişlerdir. Literatürlerdeki bu farklılıklar kullanılan materyallerin genetik farklılığının yanı sıra çalışmanın yürütüldüğü bölgelerin değişen iklim koşullarından ve agroteknik uygulamalar arasındaki farklılıktan kaynaklandığı düşünülmektedir.

Çalışmada incelenen ve verim parametresi olarak bilinen bir diğer parametre bitkide kapsül sayısı bakımından genotiplerin etkisi istatistiksel olarak $(\mathrm{p}<0.01)$ önemli olmuştur. En yüksek bitki başına kapsül sayısı değeri (4.70) Hatay popülasyonundan elde edilmiş, bunu Çameli çeşidi (4.50) takip etmiştir. Bununla birlikte Çameli çeşidi, Hatay, Uşak ve Burdur popülasyonları arasında bitki başına kapsül sayısı bakımından istatitistiki olarak farklılık görülmemiştir. Diğer taraftan bitkide kapsül sayısının en düşük (2.87) olduğu popülasyon Diyarbakır lokasyonundan elde edilen yerel popülasyon olmuştur. (Çizelge 3). Daha önce yürütülen araştırmalar neticesinde bitkide kapsül sayısını; Baytöre (2011) 5.40-7.22 adet, Taqi (2013) 4.5-4.9 adet, Tektaş (2015) 15.23-25.10 adet ve Kılıç ve Arabacı (2016) 5.5516.17 adet olarak belirlemiş, bu değerlerin araştırmamızda bulunan değerlerden daha yüksek olduğu görülmüştür. Ancak değerlerimizin Kara vd. (2015)'ın Eskişehir lokasyonunda bildirdiği 2.1-4.00 adet değerlerinden ise daha yüksek olduğu saptanmıştır. Bitki başına kapsül sayısı bakımından elde edilen değerler arasındaki farklılıklar kullanılan genotiplerin genetik yapılarının farklılığından, çalışmaların yürütüldüğg̈ ekolojilerin ve başta ekim zamanı olmak üzere yetiştiricilikteki uygulamaların farklılığ izah edilebilmektedir.

En önemli verim komponentlerinden biri olan kapsül başına tohum ağırllğı birim alan tohum verimi açısından önemli bir sslah kriteri olarak değerlendirilmektedir. Çalışmada yer alan genotiplerin kapsül başına tohum ağırlığı değerleri incelendiğinde 0.23-0.37 gr arasında değişim gösterdiği, genotipler arasında istatistiki farklılıklar $(\mathrm{p}<0.01)$ olduğu tespit edilmiştir. En düşük kapsül başına tohum ağıllığı Burdur yerel popülasyonunda $(0.23 \mathrm{gr})$ kaydedilirken, en yüksek değerler Hatay $(0.37$ gr $)$ ve Diyarbakır (0.30 gr) yerel popülasyonlarında kaydedilmiş, her iki popülasyon arasında istatistiki olarak farklılık görülmemiştir (Çizelge 3). Kılıç ve Arabacı (2016) Aydın koşullarında yaptıkları çalışmada kapsül başına tohum ağırlığını 0.21-0.32 g bularak araştırmamızın sonuçlarını teyit etmiş, Tekirdağ koşullarında Baytöre (2011) ise yapmış olduğu çalışmada araştırmamızdan elde edilen değerlerden daha yüksek değerler (1.27-1.69 g) tespit etmiştir. Bu farklılıkların genotiplerin farklı genetik yapılarından ve çevre faktörlerinin etkisinden meydana geldiği söylenebilir.

Çörek otu genotipleri arasında bin tohum ağırlığı bakımından istatistiksel anlamda iki farklı grubun oluştuğu Çizelge 3 'te görülmektedir. Buna göre istatistiksel anlamda Hatay ve Diyarbakır genotiplerinden elde edilen sonuçlar bir grupta yer alırken, diğer genotiplerden elde edilen sonuçlar da farklı bir gruba dahil olmuştur. En yüksek bin tohum ağırlıkları sırasıyla Diyarbakır (3.35 g), Uşak $(3.30 \mathrm{~g})$, Hatay $(3.20 \mathrm{~g})$ popülasyonları ile Çameli (3.00 g) çeşidinde, en düşük bin tohum ağırlığı ise Burdur (2.45 g) popülasyonunda belirlenmiştir. Yapılan literatür çalışmasında çörekotunda bin tohum ağırlığının 1.213.16 g arasında değiştiği belirlenmiştir (Akgören, 2011; Taqi, 2013; Tavas vd., 2014; Kara vd., 2015; Tektaş, 2015; Kılıç ve Arabacı, 2016; Koşar ve Özel, 2018; Saraç, 2019). Çalışmamızda elde edilen bin tohum ağırlığı değerlerinin literatür değerlerinden genel olarak yüksek olduğu görülmektedir. $\mathrm{Bu}$ durum muhtemelen çalısmalarda kullanılan genotiplerin farklı genetik yapısından, farklı 
ekolojik koşullardan ve ekim zamanı gibi yetiştiricilik uygulamalarının değişikliğinden kaynaklanmaktadır. Nitekim kışlık ekim koşullarında yazlık ekim koşullarına nispetle bin tohum ağırlığı değerlerinin daha fazla alındığ rapor edilmiştir (Öz, 2014; İnan, 2020).

Çörek otu bitkisinin esasen tohumu kullanıldı̆̆ı için bütün agronomik uygulamaların nihai hedefi tohum verimini arttırmaktır. Dekara tohum verimi bakımından çalışmada kullanılan genotipler \% 1 önemlilik düzeyinde farklılık göstermiştir. En yüksek tohum verimi Hatay popülasyonundan (119.26 kg/da) alınırken, en düşük tohum verimi Çameli çeşidinden $(66.55 \mathrm{~kg} / \mathrm{da})$ alınmıştır. Ancak Çameli çeşidi, Uşak, Diyarbakır ve Burdur popülasyonlarının tohum verimi arasında istatistiki olarak farklılık görülmemiştir. Uşak ekolojik koşullarında yapılan kışlık ekimde kullanılan genotiplerin (popülasyon/çeşit) ortalama verimi ise $82.05 \mathrm{~kg} / \mathrm{da}$ olarak belirlenmiştir (Şekil 2 ve Çizelge 3). Çalışmada kullanılan genotiplerin tohum verimleri arasındaki farklılık tohumların genetik yapılarının farklılığı ile açıklanabilir.

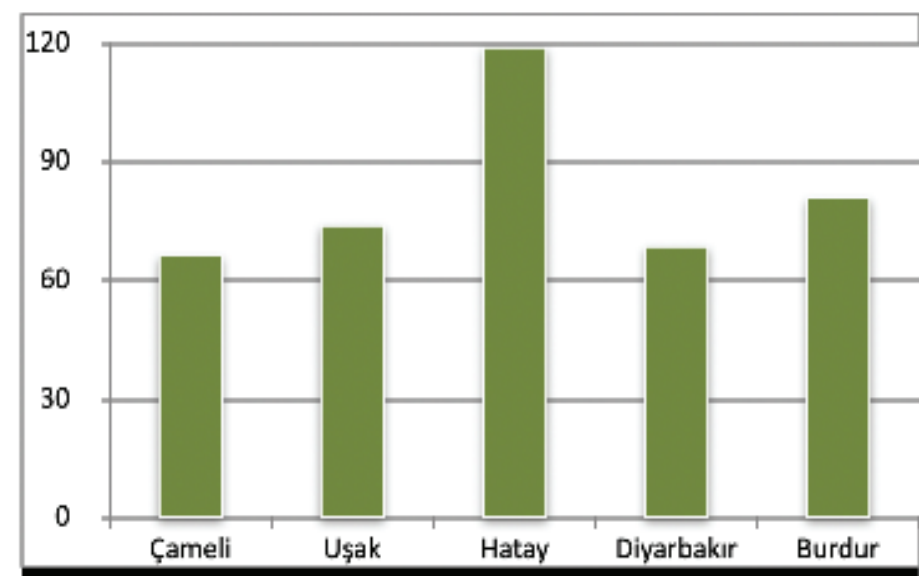

Şekil 2. Çörek otu genotiplerinin tohum verimi $\left(\mathrm{kg} \mathrm{da}^{-1}\right)$

Çalışmanın yürütüldüğü Uşak ekolojik koşullarında yazlık ekim zamanında yürütülen bir çalışmada çörek otu popülasyonlarının ve çameli çeşidinin ortalama tohum veriminin $30-55 \mathrm{~kg} / \mathrm{da}$ arasında elde edildiği bildirilmiştir (Can vd., 2021). Uşak ilinde kışlık ekim zamanında yürütülen bu çalışmada elde edilen tohum verimi değerleri $(66.55-119.26 \mathrm{~kg} / \mathrm{da})$ dikkale alındığında, Can vd. (2021)'nin yazlık ekimde elde ettiği en yüksek tohum veriminden $(55 \mathrm{~kg} / \mathrm{da})$ bu çalışmada elde edilen en düşük tohum veriminin $(66.55 \mathrm{~kg} / \mathrm{da})$ daha fazla olduğu görülmektedir. Diğer taraftan çörek otu üzerine özellikle son 10 yılda yürütülen bir çok çalışmada tohum verimini Baytöre (2011) 28.4-43.5 kg/da, Taqi (2013) 82.8-127 $\mathrm{kg} / \mathrm{da}$, Turan (2014) 87.2-116.2 kg/da, Tektaş (2015) $71.9-118.8 \mathrm{~kg} / \mathrm{da}$, Kara ve ark. (2015) $18.78-94.03 \mathrm{~kg} /$ da, Kılıç ve Arabacı (2016) 28.07-92.35 kg/da, Koşar ve Özel (2018) 28.23-107.41 kg/da ve İnan (2020) 31.49$49.11 \mathrm{~kg} / \mathrm{da}$ arasında belirlemişlerdir. Bu çalışmada birim alana tohum verimi bakımından elde edilen değerlerin önceki çalışmalarda elde edilen değerlerden farklı olması, çalışmalarda kullanılan genotiplerin, çalışmaların yürütüldüğü ekolojilerin ve agronomik uygulamaların farklılıklarından kaynaklanmaktadır.

\section{SONUÇ VE ÖNERILER}

Bu çalışma, son yıllarda çörek otu ekim alanları hızla artan Uşak ilinin ekolojik koşullarında farklı çörek otu genotipleri (popülasyon/çeşit) kullanılarak kışlık ekim zamanında yapılan ilk çalışma olması nedeniyle önem taşımaktadır. Çalışmada yer alan tüm çörek otu genotiplerinin kışlık ekim zamanında başarıyla yetiştirildiği belirlenmiştir. Çalışmadan elde edilen sonuçlar, çörek otunun tohum verimi ve verim öğeleri üzerinde genotiplerin önemli etkilere sahip olduğunu göstermiştir. Yürütülen bu çalışmada incelenen çörek otu genotipleri içinde en yüksek tohum verimi (119.26 $\left.\mathrm{kg} \mathrm{da}^{-1}\right)$ ile Hatay popülasyonu öne çıkmıştır. Kışlık ekimde yazlık ekime göre daha yüksek verim alındığı dikkate alındığında Uşak gibi çörek otu ekim alanlarının fazla olduğu bölgelerde araştırma çalışmalarının arttırılması özellikle kışlık çörek otu hat ve çeşitlerini geliştirmek üzere Ar-Ge çalışmalarına ağırlık verilmesinin uygun olacağı değerlendirilmektedir.

\section{AÇIKLAMA}

Çalışmanın yürütülmesi ve sonuçların yazılması esnasında araştırma ve yayın etiğine uyulmuştur. Herhangi bir "Çıkar Çatışması" bulunmamaktadır. 


\section{KAYNAKLAR}

Akgören, G. (2011). Bazı Çörek Otu (Nigella sativa L.) Popülasyonlarının Tarımsal Özellikleri. Yüksek Lisans Tezi, Eskişehir Osmangazi Üniversitesi, Eskișehir.

Anonim, (2019a). Türkiye İstatistik Kurumu. Dış Ticaret İstatistikleri. https://biruni.tuik.gov.tr/disticaretapp/ disticaret.zul?param $1=25 \&$ param $2=0 \&$ sitcrev $=0 \& \mathrm{i}$ sicrev $=0$ \&sayac $=5802$

Anonim, (2019b). Türkiye İstatistik Kurumu. Bitkisel Üretim İstatistikleri. https://biruni.tuik.gov.tr/ medas $/$ ?locale $=$ tr

Baydar, H. (2013). Tibbi, Aromatik ve Keyf Bitkileri Bilimi ve Teknolojisi. Süleyman Demirel Üniversitesi Ziraat Fakültesi, Yayın No: 51, Isparta.

Baytöre, F. (2011). Bazı Çörek Otu (Nigella sativa L.) Popülasyonlarının Verim ve Verim Kriterlerinin Belirlenmesi. Yüksek Lisans Tezi, Namık Kemal Üniversitesi, Tekirdağ.

Can, M. (2020). Çörek Otu Tarımında Üretici Davranışlarının Belirlenmesi, Sorunlar ve Çözümler: Uşak İli Örneği. Ziraat Mühendisliği, 370, 18-33.

Can, M., Katar, D., Katar, N., Bağc1, M., Subaşı, İ. (2021). Yield and Fatty Acid Composition of Black Cumin (Nigella sativa L.) Populations Collected from Regions under Different Ecological Conditions. Applied Ecology and Environmental Research, 19(2), 1325-1336. DOI: http://dx.doi. org/10.15666/aeer/1902_13251336.

Eren, Y. (2020). Hatay Ekolojik Koşullarında Çörek Otu (Nigella sativa L.) Bitkisinin Farklı Ekim Zamanlarında Verim ve Verim Unsurlarının Belirlenmesi. Yüksek Lisans Tezi, Hatay Mustafa Kemal Üniversitesi, Hatay.

Gün, M. (2012). Kutsal Tohum (Nigella sativa): Çörek Otunun İyileştirici Etkisine İlişkin Bazı Bilgiler. Mersin Üniversitesi Tıp Fakültesi Lokman Hekim Tıp Tarihi ve Folklorik Tıp Dergisi, 2(1), 43-46.

İnan, M. (2020). Yarı Kurak Koşullarda Ekim Zamanlarının Çörek Otu (Nigella sativa L.) Verim ve Verim Özelliklerine Etkisi. Türk Tarım ve Doğa Bilimleri Dergisi, 7(1), 32-37.

Kara, N., Katar, D., Baydar, H. (2015). Yield and Quality of Black Cumin (Nigella sativa L.) Populations: The Effect of Ecological Conditions, Turk J Field Crops, 20(1), 9-14.

Khan, M.A., Han-chun Chen, H.C.H., Tania, M., Zhang, D.Z. (2011). Anticancer Activities of Nigella sativa (Black Cumin). African Journal of Traditional, Complementary and Alternative Medicines, 8 (S), 226-232.

Kılıç, C., Arabacı, O. (2016). Çörek Otu (Nigella sativa L.)'nda Farklı Ekim Zamanı ve Tohumluk Miktarının Verim ve Kaliteye Etkisi. Adnan Menderes Üniversitesi Ziraat Fakültesi Dergisi, 13(2), 49-56.

Koşar, İ., Özel, A. (2018). Çörek Otu (Nigella sativa L.) Çeşit ve Popülasyonlarının Karakterizasyonu: I. Tarımsal özellikler. Harran Tarım ve Gıda Bilimleri Dergisi, 22(4), 533-543.

Öz, A. (2014). Farklı Ekim Zamanı, Sıra Aralığı ve Ekim Sıklığının Çemen'in (Trigonella foenumgraecum L.) Verim ve Bazı Verim Unsurları Üzerine Etkisi. Yüksek Lisans Tezi, Eskişehir Osmangazi Üniversitesi, Eskişehir.

Özel, A., Demirel, U., Güler, İ., Erden, K. (2009). Farklı Sıra Aralığı ve Tohumluk Miktarlarının Çörek Otunda (Nigella sativa L.) Verim ve Bazı Tarımsal Karakterlere Etkisi. Harran Üniversitesi Ziraat Fakültesi Dergisi, 13(1), 17-25.

Paşa, C. (2008). Kışlık ve Yazlık Ekimin Aspir (Carthamus tinctorius L.) Bitkisinin Verimi Ve Bitkisel Özelliklerine Etkisi. Yüksek Lisans Tezi, Namık Kemal Üniversitesi, Tekirdağ.

Randhawa, M. A. (2008). Black Seed, Nigella sativa, Deserves More Attention. J Ayub Med Coll Abbottabad, 20(2), 1-2.

Saraç, S. (2019). Çörek Otu (Nigella sativa L.) Bitkisinde Kışlık Ekim Zamanında Sıra Arası Mesafe ile Ekim Normunun Verim ve Bazı Kalite Kriterlerine Etkisi. Yüksek Lisans Tezi, Tekirdağ Namık Kemal Üniversitesi, Tekirdağ.

Sultana, S., Das, B., Chandra Rudra, B., Das, G., Banaz Alam, M.D. (2018). Effect of Date of Sowing on Productivity of Black Cumin. International Journal of Current Microbiology and Applied Sciences, 7(1), 1796-1800.

Taqi, H. (2013). Samsun Koşullarında Bazı Çörek Otu (Nigella sativa L.) Popülasyonlarında Önemli Tarımsal ve Kalite Özelliklerinin Belirlenmesi. Yüksek Lisans Tezi, Ondokuz Mayıs Üniversitesi, Samsun.

Tavas, N., Katar, N., Aytaç, Z. (2014). Eskişehir Ekolojik Koşullarında Yetiştirilen Çörek Otu (Nigella sativa L.)'nda Verim, Verim Özellikleri ve Sabit Yağ Bileşenleri. II.Tıbbi Aromatik Bitkiler Sempozyumu, s. 623-629, Yalova.

Tektaş, E. (2015). Harran Ovası Koşullarında Birim Alandaki Tohum Sayısının Çörek Otu (Nigella sativa L.)'nun Verim ve Bazı Bitkisel Özelliklerine Etkisi. Yüksek Lisans Tezi, Harran Üniversitesi, Şanlıurfa.

Thilakarathna, R.C.N., Madhusankha, G.D.M.P., Navaratne, S.B. (2018). Morphological Characteristics of Black Cumin (Nigella sativa) Seeds. Chemistry Research Journal, 3(3), 40-45. 
Tonçer, Ö., Kızıl, S. (2004). Effect of Seed Rate on Agonomic and Technologic Characters of Nigella sativa $L$. International Journal of Agiculture and Biology, 6(3), 529-532.

Turan, Y.S. (2014) Fosfor Dozlarının Çörek Otunun (Nigella sativa L.) Verim ve Kalitesine Etkisi. Yüksek Lisans Tezi, Eskişehir Osman Gazi Üniversitesi, Eskişehir.

Wajs, A., Bonikowski, R., Kalemba, D. (2008). Composition of Essential Oil from Seeds of Nigella sativa L. Cultivated In Poland. Flavour and Fragrance Journal, 23, 126-132.

Woo, C.C., Kumar, A.P., Sethi, G., Tan, K.H. (2012). Thymoquinone: Potential Cure for İnflammatory Disorders and Cancer. Biochem Pharmacol, 83, 443-445. 